\title{
MEMBANGUN PEMAHAMAN KEWIRAUSAHAAN DAN PENGETAHUAN EKONOMI UNTUK MENINGKATKAN KINERJA BAGI PELAKU UKM CILODONG BERKARYA DI DEPOK
}

\author{
Desmintari $^{1}$, Lina Aryani ${ }^{2}$, dan Pusporini ${ }^{3}$ \\ ${ }^{1}$ Fakultas Ekonomi dan Bisnis, Universitas Pembangunan Nasional "Veteran” Jakarta \\ Email: desmintari@yahoo.com \\ ${ }^{2}$ Fakultas Ekonomi dan Bisnis, Universitas Pembangunan Nasional "Veteran" Jakarta \\ Email: lina.aryani59@gmail.com \\ ${ }^{3}$ Fakultas Ekonomi dan Bisnis, Universitas Pembangunan Nasional "Veteran" Jakarta \\ Email: pusporini61@yahoo.com
}

\begin{abstract}
History has shown that Small and Micro Enterprises (MSMEs) in Indonesia continue to exist and develop with the economic crisis that has plagued the country since 1997, even becoming a rescue valve for the nation's economic recovery because of its ability to make a significant contribution to the GDP of the city of Depok and employment. At present the ability and knowledge of small businesses towards management science is still very limited, especially in the field of entrepreneurship, so that in business management they often experience obstacles. The high interest of participants in Community Service Activities this time can be demonstrated by the ability of members of UKM Cilodong Karya to understand more deeply the problems of entrepreneurship / interpreneursip and economic understanding in general and aims to provide socialization of knowledge about entrepreneurship and knowledge of the economy in order to gain understanding, innovation that ultimately will increase business by making profits and making families more prosperous and the GDP of the city of Depok will increase. Abdimas activities took place smoothly and were attended by participants as expected. In addition, participants can understand the material on entrepreneurship and economics, indicated by the question and answer and active participation of most participants. Based on the results of this abdimas implementation, the next abdimas participants in order to be able to improve the ability and spirit of entrepreneurship more compactly for those whose businesses are similar or have similarities to the goal if there are large orders can be done collectively.
\end{abstract}

Keywords: Enterpreneurship, Economy, Depok GDP

\begin{abstract}
ABSTRAK
Sejarah telah menunjukkan bahwa Usaha Kecil dan Mikro (UMKM) di Indonesia tetap eksis dan berkembang dengan adanya krisis ekonomi yang telah melanda negeri ini sejak tahun 1997, bahkan menjadi katup penyelamat bagi pemulihan ekonomi bangsa karena kemampuannya memberikan sumbangan yang cukup signifikan pada PDB kota Depok maupun penyerapan tenaga kerja. Saat ini kemampuan dan pengetahuan para usaha kecil terhadap ilmu manajemen masih sangat terbatas khususnya di bidang kewirausahaan, sehingga dalam pengelolaan bisnis mereka sering kali mengalami hambatan. Tingginya minat peserta dalam Kegiatan Pengabdian Pada Masyarakat kali ini dapat ditunjukkan dengan mampunya anggota UKM Cilodong Berkarya memahami lebih dalam masalah kewirausahaan/interpreneursip dan pemahaman ekonomi secara umum serta bertujuan untuk memberikan sosialisasi mengenai pengetahuan tentang kewirausahaan dan pengetahuan tentang ekonomi guna mendapatkan pemahaman, inovasi yang akhirnya akan meningkatkan usaha dengan mendapatkan keuntungan dan membuat keluarga semakin sejahtera serta GDP kota Depok menjadi meningkat. Kegiatan abdimas berlangsung dengan lancar dan dihadiri oleh peserta sesuai dengan yang diharapkan. Selain itu peserta dapat memahami materi tentang kewirausahaan dan ekonomi, ditunjukkan dengan adanya tanya jawab dan partisipasi aktif dari sebagian besar peserta. Berdasarkan hasil pelaksanaan abdimas ini, peserta abdimas selanjutnya supaya dapat meningkatkan kemampuan dan jiwa wirausaha dengan lebih kompak yaitu bagi yang usahanya mirip atau mempunyai kesamaan dengan tujuan bila ada pemesanan yang besar bisa dikerjakan secara kolektif.
\end{abstract}

Kata kunci: kewirausahaan; ekonomi ; GDP kota Depok; UMKM

\section{PENDAHULUAN}

Dalam pembangunan ekonomi kerakyatan, UKM mempunyai peranan yang penting dan strategis untuk mewujudkan struktur dunia usaha nasional yang kokoh. Usaha Kecil dan Menengah (UKM) di berbagai negara termasuk di dalam tatanan kehidupan dunia ekonomi internasional, Negara 
dengan tingkat ekonomi yang tinggi adalah Negara yang memiliki jumlah pengusaha lebih dari satu persen dari total jumlah penduduknya. Indonesia merupakan salah satu penggerak perekonomian rakyat yang tangguh. Hal ini karena rata-rata dari para pelaku usaha tersebut berasal dari industri keluarga atau rumahan.

Agar dapat meningkatkan kesempatan, kemampuan dan perlindungan terhadap pelaku UKM, telah ditetapkan berbagai kebijakan tentang pemberdayaan UKM yang dilakukan dengan cara Penumbuhan iklim usaha yang mendukung pengembangan Usaha Mikro, Kecil, dan Menengah dan Pengembangan dan pembinaan Usaha Mikro, Kecil, dan Menengah. Sebagai upaya untuk meningkatkan kemampuan dan peran serta kelembagaan UKM dalam perekonomian nasional, maka pemberdayaan tersebut perlu dilaksanakan oleh Pemerintah, Pemerintah Daerah, Dunia Usaha, dan masyarakat secara menyeluruh, sinergis, dan berkesinambungan.

Data Kementerian Koperasi dan Usaha Kecil Menengah (Kemenkop dan UKM) menunjukkan bahwa 97\% lapangan kerja diberikan oleh UKM sehingga berkontribusi signifikan mengurangi pengangguran di Indonesia. Melihat peran penting tersebut, maka dibutuhkan dukungan dari seluruh pihak untuk mengembangkan dan mewujudkan UKM yang maju, mandiri, dan modern. Sebagaimana diatur pada pasal 7 Undang-Undang Republik Indonesia Nomor 20 Tahun 2008 Tentang Usaha Mikro, Kecil Dan Menengah, Pemerintah dan Pemerintah Daerah menumbuhkan Iklim Usaha dengan menetapkan peraturan perundang-undangan dan kebijakan yang meliputi aspek pendanaan, sarana dan prasarana, informasi usaha, kemitraan, perizinan usaha, kesempatan berusaha, promosi dagang, dan dukungan kelembagaan. Sedangkan dunia usaha dan masyarakat berperan serta secara aktif membantu upaya pemerintah dan pemerintah daerah dalam menumbuhkan iklim usaha tersebut. Pada tahun 2015, jumlah UKM mencapai 59.267.759 unit usaha yang tersebar diseluruh Indonesia. Penyebaran pelaku UKM hampir merata seluruh Indonesia. Pola seperti ini menjadikan UMKM secara konseptual akan mudah dioptimalkan sebagai ujung tombak pertumbuhan perekonomian nasional jika mendapatkan perhatian dan bimbingan untuk menjadikannya lebih berkembang.

Sebagai contoh, UMKM di Kota Depok telah memberikan kontribusi positif untuk pendapatan asli daerah Kota Depok yang mencapai angka 11 persen, dengan penyerapan tenaga kerja sebesar 13 persen. Sebagai bentuk dukungan UKM di Kota Depok, maka Pemerintah Kota Depok merencanakan membangun 1.000 kios yang ditujukan untuk Usaha Kecil Menengah (UKM) lokal yang ditagerkan selama 5 tahun dengan mekanisme penyediaan 200 kios pada tiap tahunnya. Bentuk dukungan lain untuk UMKM yaitu Dinas Koperasi dan Usaha Mikro (DKUM) memberikan fasilitas bagi para pelaku usaha mikro kecil menengah untuk mengembangkan usahanya yang berupa bantuan modal yang diberi pinjam oleh DKUM Kota Depok.

Permodalan yang ditawarkan DKUM Kota Depok berasal dari bank maupun lembaga nonbank. Jumlah modal dan bunga yang diberikan juga berbeda-beda, tergantung kebijakan bank pemberi modal. Pihak bank/ lembaga keuangan tersebut biasanya akan mensyaratkan laporan keuangan untuk menilai kelayakan kredit dari usaha tersebut. Karena pada umumnya mereka tidak mempunyai keterampilan khusus dan sangat kekurangan modal kerja. Oleh sebab itu, produktivitas dan pendapatan mereka cenderung lebih rendah daripada kegiatan-kegiatan bisnis lainnya.

Pada abdimas ini tim pengabdi dengan memfokuskan pada mitra UKM Cilodong Berkarya Kota Depok yang dibentuk pada bulan Oktober 2018 untuk meningkatkan produk Mikro yang mengolah hasil pertanian, perkebunan, perikanan, catering, craft dan fashion guna mendapatkan informasi 
untuk pengembangan usahanya serta meningkatkan taraf hidup dalam keluarga serta lingkungan masyarakat sekitarnya dan yang selanjutnya berkembang menjadi UKM Cilodong Berkarya. Usaha Kecil Menengah Cilodong Berkarya (UKM Ciber) merupakan suatu wadah yang peduli terhadap usaha kecil dan mikro dibidang pertanian untuk pengolahan hasil pertanian, perikanan, perkebunan, catering, pakaian/ Fashion, craft dll yang beranggotakan 300 pelaku UKM.

Produk unggulan yang saat ini sedang dikembangkan oleh salah satu tokoh perempuan Depok khususnya Kecamatan Cilodong, Tanti Guntari yaitu Bolenesia Juara Depok. Produk kuliner berbahan baku pisang dengan berbagai toping rasa ini yang mampu memanjakan lidah para penggemar kuliner. Dengan harga yang sangat terjangkau tapi memiliki rasa yang luar biasa, kini Bolenesia Juara Depok sudah banyak di pesan dari berbagai kalangan masyarakat. Dalam pengolahan pangan hasil pertanian dan perkebunan antara lain hasil olahan pangan tanaman lidah buaya, singkong, pisang, belimbing dewa dengan memanfaatkan lahan tidur. Jenis Kegiatan UKM Cilodong, seperti pada Tabel 1.

Tabel 1. Jenis Kegiatan UKM Cilodong

\begin{tabular}{|c|c|c|}
\hline Bidang & Jenis & Hasil Olahan \\
\hline Pertanian & $\begin{array}{l}\text { Beras merah } \\
\text { Beras Hitam }\end{array}$ & Tepung \& aneka olahan beras merah dan hitam \\
\hline Perkebunan & $\begin{array}{l}\text { Lidah Buaya } \\
\text { Singkong } \\
\text { Pisang } \\
\text { Blimbing }\end{array}$ & $\begin{array}{l}\text { Bolu, aneka minuman,kue kering, jus, Jenang/dodol } \\
\text { dll }\end{array}$ \\
\hline Perikanan & Gurameh, Lele & Masakan Matang, pepes, pecak ikan dll \\
\hline Peternakan & Ayam & $\begin{array}{l}\text { Masakan dari ayam yang sudah matang ( Ayam } \\
\text { Kalasan dll) }\end{array}$ \\
\hline Fashion & $\begin{array}{l}\text { Pakaian } \\
\text { Mukena dll }\end{array}$ & $\begin{array}{l}\text { Baju Pria, wanita dan anak-anak juga mukena, } \\
\text { bordir dll }\end{array}$ \\
\hline Craft & $\begin{array}{l}\text { Berbagai } \\
\text { Kreatifitas cidera } \\
\text { mata }\end{array}$ & Inovasi pada bahan yang ada di sekitar Cilodong \\
\hline
\end{tabular}

Berdasarkan kegiatan UKM Cilodong Berkarya tersebut yang sifatnya berlangsung setiap minggu dengan membuka gerai yang telah dikoordinir di GDC (Grand Depok City) pasar kaget dengan menggunakan lapak.

Kewirausahaan adalah mengidentifikasi, mengembangkan, dan membawa visi tersebut bisa berupa ide inovatif, peluang, cara yang lebih baik dalam menjalankan sesuatu. Hasil akhir dari proses tersebut adalah penciptaan usaha baru yang dibentuk pada kondisi resiko atau ketidakpastian. Wirausaha adalah pejuang atau pahlawan yang berbuat sesuatu.Sedangkan secara epistimologi, kewirausahaan adalah nilai yang diperlukan untuk memulai suatu usaha atau proses dalam mengerjakan suatu yang baru dan sesuatu yang berbeda.

1. Jiwa kewirausahaan pada setiap orang yang memiliki perilaku inovatif dan kereatif dan pada setiap orang yang menyukai perubahan, pembauran, kemajuan dan tantangan, misalnya birokrat, mahasiswa, dosen, dan masyarakat lainnya. Adapun hakekat kewirausahaan, menurut beberapa ahli sebagai berikut:Kewirausahaan adalah suatu proses dalam mengerjakan sesuatu yang baru (creative), dan sesuatu yang berbeda (innovative) yang bermanfaat meberi nila lebih (Suryana, 2006). 
2. Kewirausahaan adalah suatu proses penerapan kreativitas dan inovasi dalam memecahkan persoalan dan menemukan peluang untuk memperbaiki kehidupan usaha (Zimmerer, 2008)

3. Kewirausahaan adalah usaha menciptakan nilai tambah dengan jalan mengkombinasikan sumber-sumber melalui cara-cara baru dan berbeda untuk memenangkan persaingan. Nilai tambah tersebut dapat diciptakan dengan cara mengembangkan teknologi baru, menemukan pengetahuan baru, menemukan cara baru untuk menghasilkan barang dan jasa yang lebih efisien, memperbaiki produk dan jasa yang sudah ada, dan menemukan cara baru untuk memberikan kepuasan kepada konsumen (Suryana, 2006).

Permasalahan ekonomi dengan keinginan dan kebutuhan manusia yang banyak namun sumber daya atau faktor-faktor produksi terbatas, dengan demikian harus ada pilihan-pilihan dalam memutuskan semua yang dibutuhkan dan bagaimana dalam perekonomian peran daripada UKM sehingga meningkatkan GDP kota Depok.

\subsection{Permasalahan Mitra}

Para pelaku UKM Cilodong Berkarya di wilayah Cilodong, Depok menghadapi beberapa permasalahan, diantaranya yaitu :

Pertama pelaku UKM Cilodong Berkarya sebagai UKM pemekaran dari UKM Pertanian, masih banyak anggota baru tersebut yang belum mengetahui dan memahami tentang kewirausahaan dan pemahaman secara formal sehingga perlunya diberikan sosialisasi.

Kedua, masih banyak dari pelaku UKM tersebut yang belum memahami tentang masalah ekonomi. Akibatnya jumlah asset atau harta kekayaan untuk usaha tidak dapat tergambarkan dengan jelas.

Ketiga, dalam menentukan harga produk seringkali dilakukan secara sederhana dan intuitif, tanpa menghitung biaya yang telah dikeluarkan secara cermat. Hal ini biasa terjadi pada pelaku UKM. Mereka tidak menghitung secara spesifik biaya bahan baku, biaya bahan penolong, biaya tenaga kerja, biaya variabel ataupun biaya overhead. Hal ini menyebabkan tidak tergambarkan dengan jelas harga pokok produk tersebut.

Berdasarkan latar belakang masalah di atas, tim Pengabdian Masyarakat merumuskan kegiatan yang mendasar yakni : Bagaimana memberikan pengetahuan mengenai kewirausahaan dan permasalahan ekonomi untuk pelaku UKM yang berada di wilayah Cilodong, Depok melalui seminar dan pelatihan.

\section{METODE KEGIATAN}

Metode pelaksanaan kegiatan pengabdian kepada masyarakat ini berupa sosialisasi, pemahaman dan pelatihan kepada pelaku usaha kecil mikro yaitu UKM Cilodong Berkarya di wilayah kota Depok (Tabel 2). Setelah menghadiri sosialisasi dan pemahaman pelaku UKM Cilodong Berkarya . Berikut adalah tahapan seminar, sosialisasi dan memberikan pemahaman yang dilakukan:

Tahap Pelaksanaan Seminar, sosialisasi dan Pelatihan

Tahap pelaksanaan pelatihan dilakukan 2 (dua) tahap, yaitu:

(1) Pemberikan. Memberikan sosialisasi dan penyuluhan pengetahuan mengenai Kewirausahaan

Kewirausahaan adalah mengidentifikasi, mengembangkan, dan membawa visi tersebut bisa berupa ide inovatif, peluang, cara yang lebih baik dalam menjalankan sesuatu. Hasil akhir dari proses tersebut adalah penciptaan usaha baru yang dibentuk pada kondisi resiko atau ketidakpastian. Wirausaha adalah pejuang atau pahlawan yang berbuat sesuatu. Sedangkan secara 
epistimologi, kewirausahaan adalah nilai yang diperlukan untuk memulai suatu usaha atau proses dalam mengerjakan suatu yang baru dan sesuatu yang berbeda.

Jiwa kewirausahaan pada setiap orang yang memiliki perilaku inovatif dan kereatif dan pada setiap orang yang menyukai perubahan, pembauran, kemajuan dan tantangan, misalnya birokrat, mahasiswa, dosen, dan masyarakat lainnya. Adapun hakekat kewirausahaan, menurut beberapa ahli sebagai berikut:Kewirausahaan adalah suatu proses dalam mengerjakan sesuatu yang baru (creative), dan sesuatu yang berbeda (innovative) yang bermanfaat meberi nila lebih (Suryana, 2006).

Kewirausahaan adalah suatu proses penerapan kreativitas dan inovasi dalam memecahkan persoalan dan menemukan peluang untuk memperbaiki kehidupan usaha (Zimmerer, 2008)

Kewirausahaan adalah usaha menciptakan nilai tambah dengan jalan mengkombinasikan sumbersumber melalui cara-cara baru dan berbeda untuk memenangkan persaingan. Nilai tambah tersebut dapat diciptakan dengan cara mengembangkan teknologi baru, menemukan pengetahuan baru, menemukan cara baru untuk menghasilkan barang dan jasa yang lebih efisien, memperbaiki produk dan jasa yang sudah ada, dan menemukan cara baru untuk memberikan kepuasan kepada konsumen (Suryana, 2006).

\section{Hakikat Kewirausahaan}

Kata wirausaha atau pengusaha diambil dari bahasa Perancis "entrepreneur" yang pada mulanya berarti pemimpin musik atau pertunjukan (Jhingan, 1999). Istilah Wirausaha sering dipakai tumpang tindih dengan istilah Wiraswasta. Ada pandangan yang menyatakan Wiraswasta sebagai pengganti dari entrepreneur sedangkan Wirausaha sebagai pengganti dari entrepreneurship (Suparman Sumahamijya, 1981). Suryana (2003) mendefinifikan kewirausahaan sebagai kemampuan kreatif dan inovatif yang dijadikan dasar, kiat dan sumber daya untuk mencari peluang menuju sukses. Lebih lanjut, Suryana (2003) menjabarkan bahwa kewirausahaan merupakan suatu kemampuan dalam menciptakan nilai tambah di pasar melalui proses pengelolaan sumber daya dengan cara-cara baru dan berbeda melalui Pengembangan teknologi baru, Penemuan pengetahuan ilmiah baru, Perbaikan produk barang dan jasa yang ada, dan Penemuan cara-cara baru untuk menghasilkan barang lebih banyak dengan sumber daya lebih efisien

\section{Jiwa dan Kompetensi Kewirausahaan}

Meredith et al (2002) menjabarkan enam nilai hakiki dalam kewirausahaan yaitu: percaya diri, berorientasi pada tugas dan hasil, keberanian mengambil risiko, kepemimpinan, berorientasi pada masa depan, dan orisinilitas (Kreativitas dan inovasi). Kepercayaan diri merupakan pendorong seseorang untuk berperilaku dan bertindak, orang yang memiliki kepercayaan diri cukup akan cenderung memilki kemampuan untuk bertindak sesuai dengan pemikirannya. Orientintasi pada tugas dan hasil yang dimiliki seseorang akan menimbulkan motif orang untuk berprestasi. Keberanian mengambil risiko merupakan spririt dasar suatu usaha. Semakin besar keberanian orang mengambil risiko semakin besar pula peluang hasil yang diperoleh. Keberanian mengambil risiko mendorong seseorang untuk berani mengambil tindakan yang baru yang kreatif dan inovatif. Kepemimpinan merupakan ujung tombak dalam pengelolaan usaha. Jiwa kepemimpinan yang baik yang dimiliki seseorang mampu meningkatkan kemampuan menejerial seseorang. Orientasi seseorang pada masa depan mampu mendorong sesorang untuk tetap belajar dan memperbaiki kesalahan sehingga dapat terus maju. Nilai hakiki dari kewirausahaan adalah keorisinilan. Dalam mengembangkan suatu usaha orisinilitas ide dalam menjalankan usaha merupakan motor penggerak utama. Suatu ide yang benar-benar baru mendorong kemajuan usaha itu sendiri. Lebih 
lanjut, Jhingan (1999) memberikan kualitas kriteria pengusaha sebagai berikut: (1) energik, banyak akal, siap siaga terhadap peluang baru, mampu menyesuaikan diri terhadap kondisi yang berubah dan mau menanggung resiko dalam perubahan dan perkembangan; (2) memperkenalkan perubahan teknologi dan memperbaiki kualitas produknya; (3) mengembangkan skala operasi dan melakukan persekutuan, mengejar dan menginvestasikan kembali labanya Suryana (2003) menjabarkan bahawa seorang wirausahawan harus memiliki keterampilan dasar yang meliputi (1) Managerial skill untuk pengelolaan usaha, (2) Conceptual skill yaitu kemampuan untuk membuat konsep usaha dan pemetaan pecahan masalah, (3) Human skill yaitu kemampuan untuk berkomunikasi dan beriteraksi dengan orang lain (4) Decision making skill yaitu kemampuan utuk mengambil keputusan dengan tepat sasaran pada waktu yang tepat juga, (5) Time managerial skill yaitu kemampuan mengelola, mengatur, dan menggunakan waktu

\section{Menumbuhkan Jiwa Kewirausahan}

Herwan Abdul Muhyi (2007) menjabarkan cara-cara uantuk menumbuhkan jiwa kewirausahaan dapat dilakukan dengan menggunakan empat cara 1. Melalui pendidikan formal. Kini berbagai lembaga pendidikan baik menengah maupun tinggi menyajikan berbagai program atau paling tidak mata kuliah kewirausahaan 2. Melalui seminar-seminar kewirausahaan. Berbagai seminar kewirausahaan seringkali diselenggarakan dengan mengundang pakar dan praktisi kewirausahaan sehingga melalui media ini kita akan membangun jiwa kewirausahaan pada diri kita 3 . Melalui pelatihan. Berbagai simulasi usaha biasanya diberikan melalui pelatihan baik yang dilakukan dalam ruangan (indoor) maupun di luar ruangan (outdoor). Melalui pelatihan ini, keberanian dan ketanggapan kita terhadap dinamika perubahan lingkungan akan diuji dan selalu diperbaiki dan dikembangkan 4. Otodidak. Melalui berbagai media kita bisa menumbuhkan semangat berwirausaha. Misalnya melalui biografi pengusaha sukses (success story), media televisi, radio majalah koran dan berbagai media yang dapat kita akses ntuk menumbuhkembangkan jiwa wirausaha yang ada di diri kita.

(2) Menjelaskan dan memberikan pemahaman mengenai ekonomi dan permasalahannya.

(3) Memotivasi para pelaku usaha agar dapat menjalankan usahanya secara profesional. Untuk melaksanakan kegiatan tersebut, digunakan beberapa metode, yaitu:

a. Metode Ceramah / sosialisasi .Metode ini dipilih untuk memberikan penjelasan berupa pengenalan dan upaya untuk memahami tentang jiwa kewirausahaan dan pemahaman dalam permasalahan ekonomi

Tabel 2. Prosedur kerja

\begin{tabular}{|c|l|l|}
\hline Tahap Ke & \multicolumn{1}{|c|}{ Kegiatan } & \multicolumn{1}{|c|}{ Indikator } \\
\hline 1. & $\begin{array}{l}\text { Memberikan sosialisasi pemahaman } \\
\text { tentang Kewirausahaan dan ekonomi }\end{array}$ & $\begin{array}{l}\text { Menilai pencapaian peningkatan } \\
\text { pemahaman materi dengan tanya } \\
\text { jawab }\end{array}$ \\
\hline 2. & $\begin{array}{l}\text { Diskusi dan evaluasi kegiatan yang } \\
\text { telah dilakukan dan potensi } \\
\text { kewirausahaan yang belum dilakukan } \\
\text { dan permasalahan serta pemahaman } \\
\text { ekonomi }\end{array}$ & $\begin{array}{l}\text { Dapat mengetahui kelemahan dan } \\
\text { kekuatan dalam pemahaman } \\
\text { kewirausahaan yang dilakukan saat } \\
\text { ini. } \\
\text { B.Dapat mengetahui peluang usaha } \\
\text { kedepan }\end{array}$ \\
\hline
\end{tabular}

b. Metode Tanya Jawab.Metode Tanya jawab sangat penting bagi para peserta pelatihan, baik disaat menerima penjelasan, serta saat mempraktekkannya. Metode ini memungkinkan pelaku bisnis UKM Cilodong Berkarya menggali pengetahuan sebanyak-banyaknya tentang kewirausahaan dan pemahaman dalam permasalahan ekonomi. 


\section{HASIL DAN PEMBAHASAN}

Sebelum tim melakukan kegiatan sosialisasi dan pemahaman tentang kewirausahaan dan ekonomi, dilakukan wawancara dengan masyarakat setempat mengenai rencana pelaksanaan abdimas. Sebelumnya, tim menanyakan apakah sudah pernah diadakan pelaksanaan kegiatan sosialisasi dan pemahaman mengenai kewirausahaan dan ekonomi dilokasi tersebut. Ternyata untuk penyuluhan kewirausahaan dan pemahaman ekonomi belum pernah diadakan sebelumnya.

Pelaksanaan pengabdian masyarakat yang dilaksanakan tim pengabdi dengan mitra pada hari Selasa, 23 Juli 2019 yang terselenggara dengan baik. Sesuai dengan rencana yang disusun oleh Tim Pengabdi. Jumlah peserta 29 orang g peserta yang ditargetkan tercapai, rencana waktu pelaksanaannya tercapai sesuai dengan jadwal yang disepakati antara warga masyarakat dengan tim Pengabdi. Diluar waktu tersebut pengabdi masih harus melayani konsultasi dari peserta pada saat ada permasalahan di dalam usahanya untuk mendapatkan solusi. Hasil kegiatan abdimas ini, dapat dilihat pada Tabel 3.

Tabel 3.Hasil kegiatan abdimas ini.

\begin{tabular}{|c|l|l|l|}
\hline Kegiatan & \multicolumn{1}{|c|}{ Materi } & \multicolumn{1}{c|}{$\begin{array}{c}\text { Indikator } \\
\text { keberhasilan }\end{array}$} & \multicolumn{1}{c|}{ Ketercapaian } \\
\hline $\begin{array}{c}\text { Pemahaman } \\
\text { dan } \\
\text { sosialisasi }\end{array}$ & $\begin{array}{l}\text { Sosialisasi, penyuluhan, } \\
\text { dan diskusi } \\
\text { kewirausahaan dan } \\
\text { pemahaman ekonomi } \\
\text { langsung }\end{array}$ & $\begin{array}{l}\text { Menilai pemahaman } \\
\text { tentang kewirausahaan } \\
\text { dan langsung melalui } \\
\text { Tanya jawab dan } \\
\text { contoh serta } \\
\text { pengalaman2 }\end{array}$ & $\begin{array}{l}\text { Peserta } \\
\text { memahami materi } \\
\text { penyuluhan dan } \\
\text { puas mengenai } \\
\text { kewirausahaan } \\
\text { dan ekonomi } \\
\text { dengan contoh } \\
\text { dan bukti nyata } \\
\text { tentang } \\
\text { enterprenuership }\end{array}$ \\
\hline
\end{tabular}

Berdasarkan hasil pelaksanaan Abdimas, peserta sosialisasi dan penyuluhan merespon secara positif dan terlihat puas. Dapat terlihat pula antusiasme peserta untuk menjadi wirausaha yang ditunjukkan dengan keaktifan berpartisipasi dalam penyuluhan. Peserta juga telah menunjukkan pemahaman mereka mengenai kewirausahaan dan ekonomi dengan bertanya dan memberikan pengalaman pribadi serta kita berikan pemahaman dan cara menyelesaikan masalah.

Hasil Monitoring dan Evaluasi

Setelah melakukan pemahaman dan sosialisasi abdimas dan dengan Hasil evaluasi dari kegiatan abdimas yang sudah dilakukan di UKM Cilodong Berkarya, Kecamatan Cilodong Kota Depok, adalah pada setiap hari minggu kebetulan anggota UKM Cilodong Berkarya banyak yang membuka lapak di Grand Depok City kami tim abdimas mengadakan tanya jawab secara tidak formal tentang dipraktekan dalam berwirausaha setelah adanya pemahaman dan sosialisasi . Hal ini sesuai dengan salah satu tujuan abdimas yaitu membantu meningkatkan pendapatan keluarga sehingga meningkatkan Produk Domestik Bruto kota Depok. 


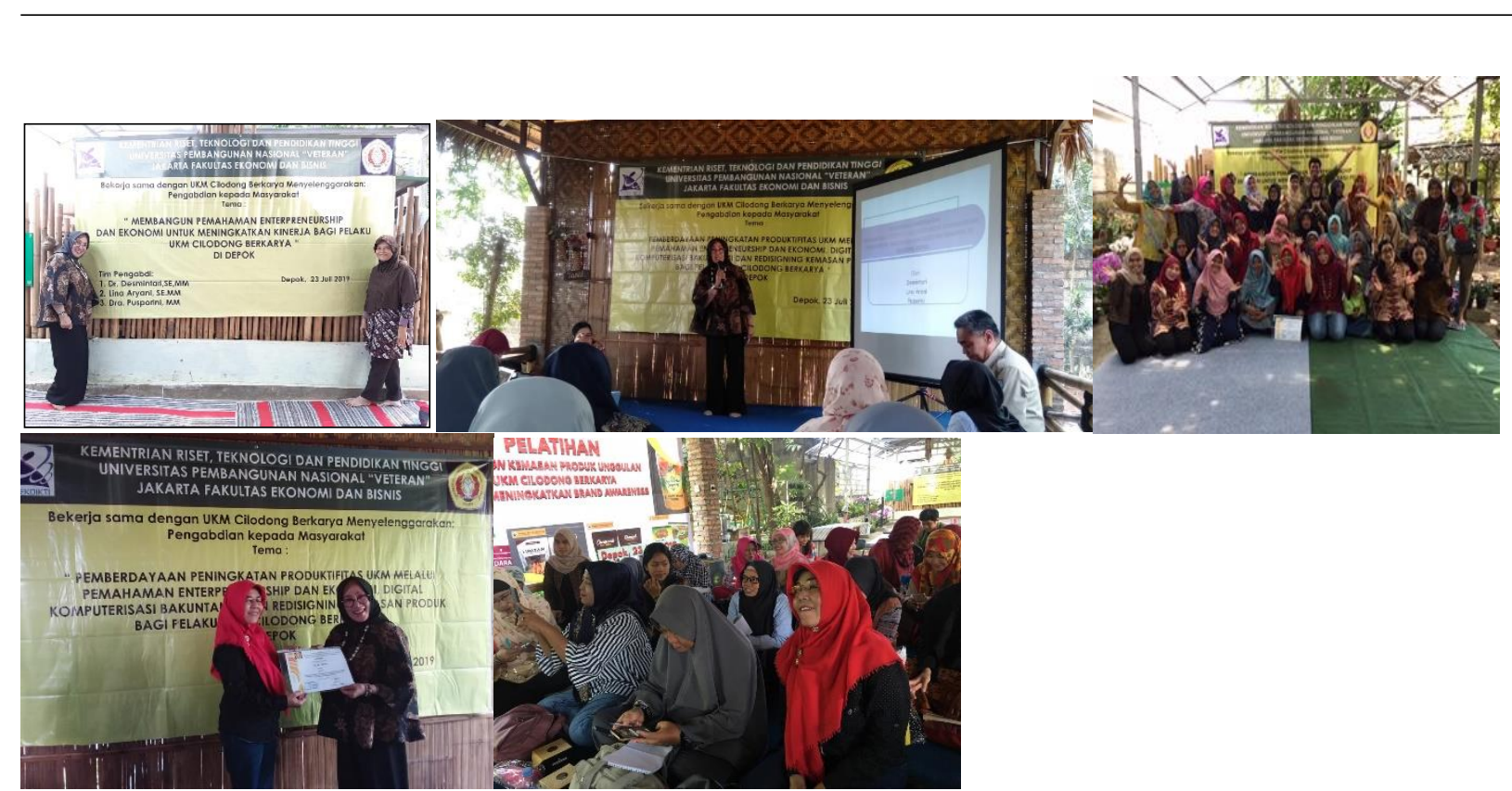

Gambar 1. Pelaksanaan Abdimas pada Cilodong Berkarya

\section{KESIMPULAN DAN SARAN}

Kegiatan Pengabdian Kepada Masyarakat dilaksanakan di UKM Cilodong Berkarya Kecamatan Cilodong, Kota Depok, dapat disimpulkan sebagi berikut :

1. Pelaksanaan Abdimas tentang Pemahaman dan sosialisasi tentang Kewirausahaan dan ekonomi bagi anggota UKM Cilodong Berkarya Kecamatan Cilodong, Kota Depok dilaksanakan pada tanggal 23 Juli 2019 dengan jumlah peserta yang hadir ada 29 orang berjalan dengan lancar sesuai dengan yang diharapkan.

2. Dari hasil pelaksanaan Abdimas, anggota UKM Cilodong Berkarya Kecamatan Cilodong, Kota Depok dapat memahami materi tentang kewirausahaan dan ekonomi dengan adanya tanya jawab sebagian besar peserta berpartisipasi.

3. Dari hasil evaluasi, diketahui bahwa anggota UKM Cilodong Berkarya Kecamatan Cilodong, Kota Depok bisa bersaing dan berinovasi sesuai dengan salah satu tujuan abdimas yaitu dapat membantu meningkatkan pendapatan keluarga serta menaikan PDB Kota Depok.

Tim pengabdi menyarankan agar anggota UKM Cilodong Berkarya Kecamatan Cilodong, Kota Depok dapat meningkatkan kemampuan dan jiwa wirausaha dengan lebih kompak bagi yang usahanya mirip atau mempunyai kesamaan dengan tujuan bila ada pemesanan yang besar bisa dikerjakan secara kolektif. Untuk rencana selanjutnya Tim pengabdi akan memberikan abdimas untuk kegiatan yang berbeda.

\section{REFERENSI}

Geoffrey G. Meredith, et. Al. (2000). Kewirausahaan Teori dan Praktek. Jakarta: Pustaka Binaman Pressindo

Herwan Abdul Muhyi, (2007) Menumbuhkan Jiwa Dan Kompetensi Kewirausahaan, Makalah: Jurusan Ilmu Administrasi Niaga Fakultas Ilmu Sosial Dan Ilmu Politik Universitas Padjadjaran Bandung

Jhingan, M.L. 1999. Ekonomi Pembangunan dan Perencanaan. Edisi keenam belas.

(Terjemahan D. Guritno). Rajawali Pers. Jakarta.

Keputusan Menteri Keuangan No. 40/KMK.06/2003 tentang Pendanaan Kredit Usaha Mikro dan Kecil.

Meredith, Geoffrey G. (2002). Kewirausahaan: Teori dan Praktek. Jakarta : PPM 
Presiden Republik Indonesia. 2008. Undang-Undang Republik Indonesia Nomor 20 Tahun 2008 Tentang Usaha Mikro, Kecil Dan Menengah.

Suparman Sumahamijaya. (1980). Membina Sikap Mental Wiraswata. Jakarta:Gunung Jati

Suryana. 2003. Kewirausahaan: Pedoman Praktis, Kiat dan Proses Menuju Sukses. Jakarta:

Salemba Empat

Sukirno S, Makro Ekonomi Teori Pengantar, Divisi Buku Perguruan Tinggi PT. Raja Grafindo Persada, Jakarta Edisi 3 Tahun 2006

Undang-Undang Republik Indonesia Nomor 20 Tahun 2008 tentang Usaha Mikro, Kecil dan Menengah.

Wahyuningsih, E.D., Setiawati, I \& Prasojo, T.A. 2017. Pemberdayaan Pelaku Usaha

Mikro Dengan Memberikan Pelatihan Pembukuan Sederhana di Desa Bangunrejo

Kecamatan Patebon Kabupaten Kendal.

Zimmerer Thomas W, Norman M Scarborough, Kewirausahaan dan Manajemen Usaha Kecil, Salemba empat, 2008. 